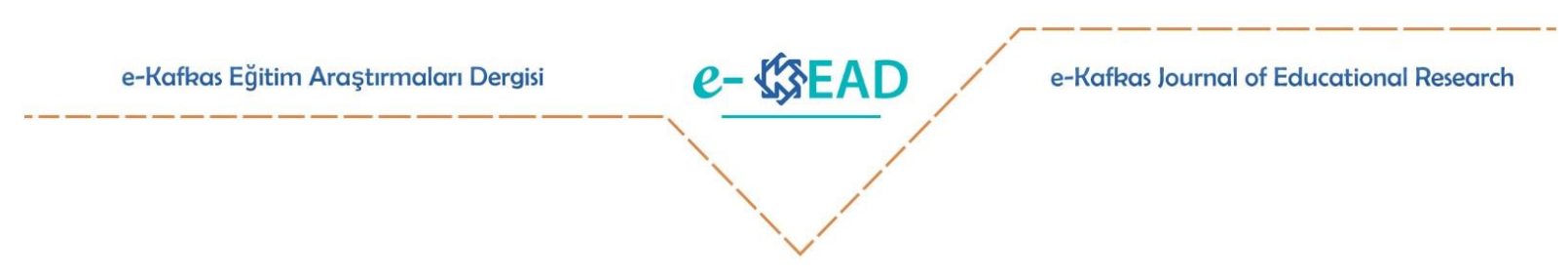

\title{
Genre Analysis in ESP: A Review of Move Analysis Models and Metadiscourse Taxonomies ${ }^{1}$
}

\section{Rabia Ötügen ${ }^{2}$ Mehmet Takkaç $^{3}$ Oktay Yağız ${ }^{4}$}

\section{To cite this article:}

Ötügen, R., Takkaç, M., \& Yağız, O. (2021). Genre analysis in ESP: A review of move analysis models and metadiscourse taxonomies. e- Kafkas Ĕ̆itim Araştırmaları Dergisi, 8, 67-85. doi: 10.30900/kafkasegt.877595

\section{Review article}

Received:09.02.2021

Accepted:28.04.2021

\begin{abstract}
Genre analysis has received much attention in the last decades. For both academic and pedagogical purposes, different genres have been analyzed in terms of their rhetorical features. In English for Specific Purposes (ESP) tradition, genre analysis focuses on communicative functions described in terms of moves and steps and linguistic properties of these functions. For such an analysis having both structural and linguistic aspects, researchers typically use models and taxonomies. However, there are several models and taxonomies in the literature that researchers can use for the analysis of different genres. Therefore, this study aims to review the move analysis models and metadiscourse taxonomies presented over many years. It clarifies the ESP approach to genre analysis and then provides a comprehensive review of the models and taxonomies offered since the second half of the twentieth century. It is expected that the study will help both researchers in the field and learners of academic writing by specifying the basics of genre analysis in ESP and providing a comprehensive account of the models and taxonomies used commonly in the genre analysis literature.
\end{abstract}

Keywords: Genre analysis, English for specific purposes (ESP), move analysis models, metadiscourse taxonomies

\footnotetext{
${ }^{1}$ This study is a part of the dissertation entitled "A Genre Analysis of the Final Chapters of ELT Dissertations Written by Turkish and Anglophone Researchers" approved by Atatürk University Graduate School of Educational Sciences in 2020.

2 (iD) Corresponding Author, Research Assistant Doctor, rabia.otugen@atauni.edu.tr, Atatürk University, Kazım Karabekir Educational Faculty, Turkey

3 (D) Author, Professor, Atatürk University, Kazım Karabekir Educational Faculty, Turkey

4 (iD) Author, Associate Professor, Atatürk University, Kazım Karabekir Educational Faculty, Turkey
} 


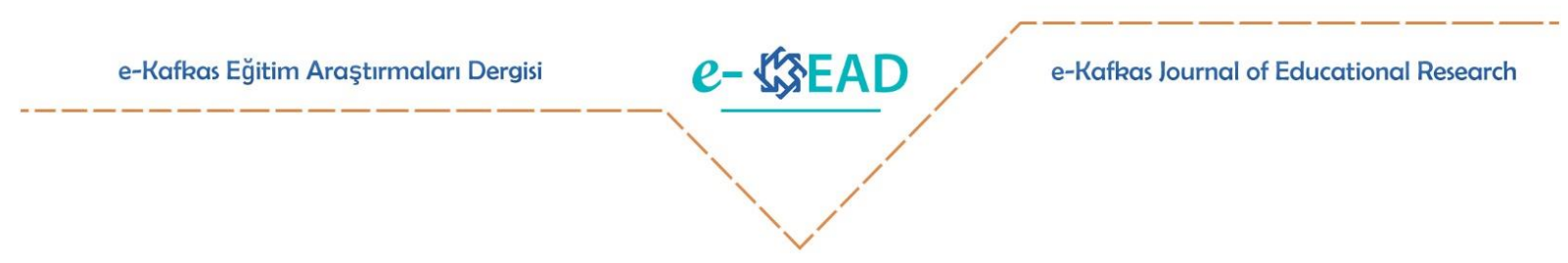

\title{
ÖAİ'de Tür Analizi: Aşama Analizi Modelleri ve Üstsöylem Taksonomileri Üzerine Bir İnceleme ${ }^{1}$
}

\author{
Rabia Ötügen² ${\text { Mehmet Takkaç }{ }^{3} \text { Oktay Yağız }}^{4}$
}

\begin{abstract}
Atıf:
Ötügen, R., Takkaç, M., ve Yağız, O. (2021). ÖAİ'de tür analizi: Aşama analizi modelleri ve üstsöylem taksonomileri üzerine bir inceleme. e- Kafkas Eğitim Araştırmaları Dergisi, 8, 67-85. doi: $10.30900 /$ kafkasegt.877595
\end{abstract}

\section{Derleme Makalesi}

Geliş Tarihi: 09.02.2021

Kabul Tarihi: 28.04 .2021

\section{$\ddot{O} \mathbf{z}$}

Tür analizi, son yıllarda büyük ilgi görmektedir. Hem akademik hem de pedagojik amaçlarla, farklı türlerden metinler retorik özellikleri açısından analiz edilmektedir. Özel Amaçlı İngilizce (ÖAİ) yaklaşımında tür analizi, aşamalar ve adımlar şeklinde tanımlanan iletişimsel işlevler ve bu işlevlerin dilsel özelliklerine odaklanır. Hem yapısal hem de dilsel yönleri olan böyle bir analiz için araştırmacılar genellikle model ve taksonomiler kullanmaktadırlar. Ancak, alan yazında araştırmacıların farklı türlerin analizi için kullanabileceği birçok model ve taksonomi bulunmaktadır. $\mathrm{Bu}$ nedenle, bu çalışma, uzun yıllar boyunca ortaya konulan aşama analizi modellerini ve üstsöylem taksonomilerini incelemeyi amaçlamaktadır. Çalışma, tür analizinde ÖAİ yaklaşımını açıklamakta ve ardından yirminci yüzyılın ikinci yarısından bu yana sunulan modellerin ve taksonomilerin kapsamlı bir incelemesini sunmaktadır. Çalışmanın, ÖAİ'de tür analizinin temelleri belirtmek ve tür analizi alanında yaygın olarak kullanılan model ve taksonomilerin kapsamlı bir özetini sunmak suretiyle, hem alandaki araştırmacılara hem de akademik yazım eğitimi alanlara yardımcı olması beklenmektedir.

Anahtar Sözcükler: Tür analizi, özel amaçlı İngilizce (ÖAİ), aşama analizi modelleri, üstsöylem taksonomileri

\footnotetext{
${ }^{1}$ Bu çalışma Atatürk Üniversitesi Eğitim Bilimleri Enstitüsü tarafından 2020 yılında kabul edilen "A Genre Analysis of the Final Chapters of ELT Dissertations Written by Turkish and Anglophone Researchers" isimli doktora tez çalışmasının bir bölümüdür.

2 (D) Sorumlu Yazar, Araştırma Görevlisi Doktor, rabia.otugen@atauni.edu.tr, Atatürk Üniversitesi, Kazım Karabekir Eğitim Fakültesi, Türkiye

3 (D) Yazar, Profesör Doktor, Atatürk Üniversitesi, Kazım Karabekir Eğitim Fakültesi, Türkiye

4 (D) Yazar, Doçent Doktor, Atatürk Üniversitesi, Kazım Karabekir Eğitim Fakültesi, Türkiye
} 


\section{Introduction}

Academic writing consists of various types of genres (e.g., books, research articles, theses, and dissertations). Each genre has its conventions and genre analysis serves for the identification of these conventions specific to each genre. The knowledge and application of genre-specific conventions may be of high importance since effective academic writing requires using the conventions appropriate to the target discourse community. Due to its importance, there has been a growing interest in the concept of genre and genre analysis in the last decades.

English for Specific Purposes (ESP) is one of the main approaches to genre and genre analysis. It "offers a system of analysis which allows observations to be made on the repeated communicative functions found in genres and the linguistic exponents of these functions" (Brett, 1994, p. 47). Through such an analysis, it is aimed to teach academic writing to especially those who are learning to write in a foreign language. Therefore, the main reason behind genre analysis is to do with pedagogical concerns. The target learners who are most commonly non-native postgraduate students or academics are expected to learn the writing conventions of the relevant genre by studying representative texts. These texts which are analyzed in terms of communicative functions and their linguistic features provide samples for learners and thus help them understand the writing conventions of the genre and write accordingly.

ESP defines genre with an emphasis on the communicative purpose pursued by the members of the related discourse community and how this purpose is related to rhetorical structures. Therefore, genre analysis in ESP typically begins with the communicative purpose and continues with the structural organization and linguistic features serving for the achievement of this communicative purpose. In such an analysis which is made in a move-step format, the identification of the moves and steps is followed by the analysis of linguistic features with which those moves and steps are associated. During the analysis process, researchers commonly use models and taxonomies, and there are different models and taxonomies in the genre analysis literature (e.g., Hyland \& Tse, 2004; Swales, 1990; Yang \& Allison, 2003). Based on these models and classifications, genre analysis has been done in numerous studies (e.g., Hirano, 2009; Kanoksilapatham, 2005; Kim \& Lim, 2013; Kwan, 2006; Loi, 2010; Nwogu, 1997; Peacock, 2002; Williams, 1999). Academic writing conventions specific to each genre; structural and linguistic elements that make genres different from each other; linguistic, disciplinary, and cultural effects on generic features; and effects of genre-based teaching on both language learning and academic writing have been investigated widely.

The increase in the number of move and metadiscourse analysis studies brings the need for studies on the models and taxonomies that can be used in such analyses. Beginning with the definition, the scope, and steps of genre analysis in ESP, the present study provides a review of the move analysis models and metadiscourse taxonomies referenced commonly in the literature. It is expected that the study will primarily help genre analysts, especially those who are new in the field, and learners of academic writing because it presents the most commonly used models and taxonomies in the genre analysis literature. It is also expected that the study will have implications for pedagogy since the review may be used for the teaching and learning of genre analysis in ESP.

\section{Genre Analysis in ESP}

The concept of genre has received extensive attention in the text analysis literature both as a subject matter of genre analysis and a tool for language instruction. ESP is one of the three main approaches to genre and it differs from other approaches (i.e., Australian Systemic Functional Linguistics -SFL, and North American New Rhetoric- NR) in terms of its perspective to the genre. Relating genres to communicative functions, SFL defines genres "as staged, goal-oriented social processes" (Martin, 2002, p. 56), associating them to discourse communities, ESP regards genres as communicative events (Swales, 1990) and putting much emphasis on situational context, NR describes genres as social and rhetorical actions (Miller, 1984). These differences in perspectives are reflected in certain properties of genre approaches among which is genre analysis.

Regarding genre analysis, ESP and SFL have both comparable and different characteristics. Although they differ in their approaches to analysis since theoretically, SFL is linguistic whereas ESL is eclectic, genre analyses in both approaches proceed from text to context. Researchers in both 
traditions tend to begin their work by textual analysis. Commonly, extending their analyses by other methods such as interviews, they reach conclusions about the context in which genres occur (Johns, 2013). New Rhetoricians, on the other hand, "begin by studying the 'context of use', the cultures and situations in which texts from a genre are found, and then turn to how individuals and their spoken and written discourses are influenced by these cultures within a specific context" (Johns, 2013, p. 2). Since they place emphasis primarily on the context, their genre analysis mainly covers ethnographic rather than linguistic methods, serving for the description of the related context. Flowerdew (2002) argues that the New Rhetoric approach can be classified as 'nonlinguistic' and the other two (i.e., SFL and ESP) as 'linguistic' because of their focal points. He explains:

ESP and Australian school take a linguistic approach, applying theories of functional grammar and discourse and concentrating on the lexico-grammatical and rhetorical realization of the communicative purposes embodied in a genre, whereas the New Rhetoric group is less interested in lexico-grammar and rhetorical structure and more focused on situational context (p. 91).

Such categorization may give the impression that genre approaches focus on either linguistic or contextual elements. However, as noted by Flowerdew (2002), it does not mean that linguistic approaches ignore contextual elements and nonlinguistic approaches find the linguistic items unimportant. The point is that "the linguistic approach looks to the situational context to interpret the linguistic and discourse structures, whereas the New Rhetoric may look to the text to interpret the situational context" (Flowerdew, 2002, pp. 91-92). Since ESP emphasizes both linguistic and contextual factors, it has been regarded as "a field that bridges linguistic and rhetorical traditions" (Bawarshi \& Reiff, 2010, p. 41). Hyland (2004) considers it eclectic and writes that "like NR, ESP employs notions of dialogism and contextual situatedness, but also draws on SFL understandings of text structure and, more sparingly, on SFL principles of pedagogy" (p. 44). He explains what makes ESP different from the other two positions by stating that it "is more linguistic than NR and more oriented to the role of social communities than SFL" (p. 44).

As an eclectic approach, ESP focuses on both contextual and linguistic elements. However, different from other approaches, it relates these elements to specific discourse communities which can be described as a group of people that "has a broadly agreed set of common (public) goals and has mechanisms of intercommunication among its members" (Swales, 1990, p. 25). ESP defines genre with an emphasis on the communicative purpose pursued by the members of the related discourse community and how this purpose is related to rhetorical structures. Swales (1990) explains:

A genre comprises a class of communicative events, the members of which share some set of communicative purposes. The purposes are recognized by the expert members of the parent discourse community, and thereby constitute the rationale for the genre. This rationale shapes the schematic structure of the discourse and influences and constrains choice of content and style (p. 58).

Since the communicative purpose is seen as the main distinctive feature of genres, genre analysis begins with the communicative purpose. Then comes the analysis and interpretation of the structural and linguistic features serving for the achievement of this communicative purpose. Such an analysis is usually made in a move-step format, first offered by Swales (1981, 1990). A move can simply be defined as a part of a text which can be subdivided into steps (i.e., strategies used as realizing the move). By achieving a particular communicative function, each move contributes to the overall purpose of the genre. "Decisions about the classification of the moves are made on the basis of linguistic evidence, comprehension of the text and understanding of the expectations that both the general academic community and the particular discourse community have of the text" (DudleyEvans, 1994, p. 226). The identification of the moves and steps, however, is followed by the analysis of lexico-grammatical features with which those moves and steps are associated. During the analysis process, methods such as interviews can also be included to provide an ethnographic perspective (see Lee, 2016).

Paltridge (2011) reminds us that there exists no certain sequence to genre analysis. That is, genre analysis can begin with either the investigation of the structural and linguistic patterns or the 
examination of the context of the text. Depending on the aim of the researcher, a text-first or contextfirst approach can be followed. However, there seems to be a general tendency to move from the macrostructure of the text towards its microstructure. It is common that genre analysis within ESP proceeds "from identifying purpose to analyzing a genre's rhetorical moves and how these moves are carried out textually and linguistically" (Bawarshi \& Reiff, 2010, p. 48). It is also common that move analysis models are used for the analysis of moves and steps, and that metadiscourse taxonomies are used for the analysis of metalinguistic elements. Many models have been offered since the first model in the field was developed by Swales in 1981 and many taxonomies have been proposed since the term metadiscourse was first introduced by Harris in 1959. The following sections provide a review of the move analysis models and metadiscourse taxonomies used commonly in the genre analysis literature.

\section{Move Analysis Models}

The pioneering move analysis model was developed by Swales in 1981. Based on the analysis of 48 research article introductions from the fields of physics, biology/medicine, and social sciences, Swales proposed a model including four moves which could further be subdivided: Establishing the field, Summarizing previous research, Preparing for the present research, and Introducing present research. In 1990, upon the findings of research studies applying the model to texts from different fields (e.g., Crookes, 1986), Swales came up with the revised version of his 1981 model. In this model, named Create a Research Space (CaRS), the moves were reduced from four to three, and Move 3 was extended to include a further concluding step in which the remaining parts of the paper are explained (Swales, 2011). According to this revised version, a research introduction typically consists of three moves (i.e., Establishing a territory, Establishing a niche, and Occupying the niche), each of which is subdivided into several steps which can be compulsory or optional.

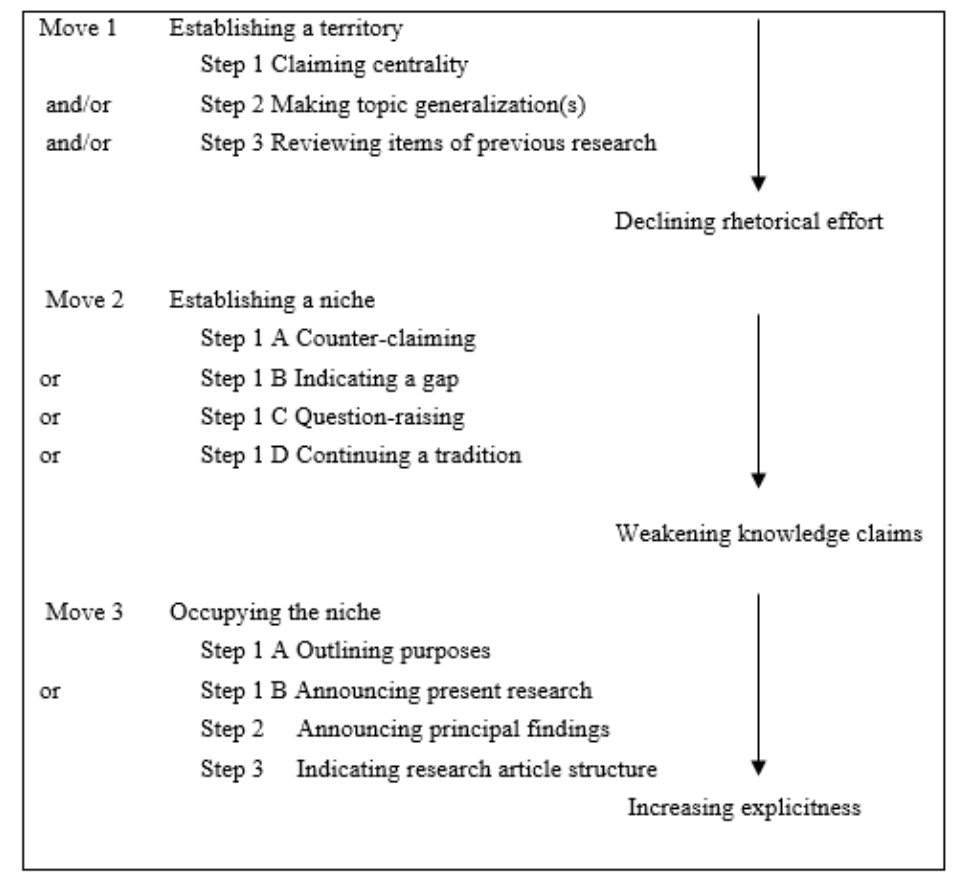

Figure 1. Swales' Create a Research Space (CaRS) Model

In the first move, Establishing a territory, a rationale for the study is provided by indicating how the research area is significant and interesting. Example sentences include "Recently, there has been growing interest in ...", "Knowledge of ... has a great importance for ...", and "Many recent studies have focused on ..." In the second move, Establishing a niche, however, a gap in the related literature is identified or questions are raised. By using sentences such as "Little is, however, known about ...", "However, it remains unclear whether ...", "Although considerable research has been devoted to ..., rather less attention has been paid to ...", it is shown that the related research area has limitations and weaknesses. This move, which is commonly signaled by words such as however, 
nevertheless, but, and yet, is followed by the third move, Occupying the niche, in which the present study is described in terms of its purpose and main features. In this move, how the gap or the questions stated in the previous move are planned to be filled or answered is specified. Example sentences to this last move include, "The aim of the present paper is to give ...", "This paper reports on the results obtained ..." and "This study was designed to evaluate ..." (Swales \& Feak, 2004, pp. 250-263). All these moves and steps are given above (see Figure 1).

This model has been used by many researchers in their genre analyses consisting of different disciplines and languages. As a result of their analyses, researchers discussed its applicability from several perspectives, and many of them offered modifications to the model. For instance, Anthony (1999) applied the model to research article introductions in the field of computer engineering and found it inadequate to account for certain features although it was effective to express the main framework of the texts. As the limitations of the model, he indicated the weak definitions of individual steps and lack of a step for evaluating the research. Applying the model to two related fields, Wildlife Behaviour and Conservation Biology, Samraj (2002) also found some limitations of the model such as the difficulty in distinguishing between the second and third steps of Move 1. She offered a modified version of the model and indicated the need for a greater degree of embedding in the Swales' model in order that it can express the structures of the analyzed research articles.

Move-based studies which follow Swalesian approach to genre analysis have provided valuable data about the organizational features of a diverse range of academic and professional genres. Inspired by Swales, many researchers have proposed move analysis models and investigated the way texts are organized in different genres. In terms of spoken genres, it seems that models for the analysis of academic conferences and lectures are common although there also exists models for other genres such as Ph.D. defenses (Mežek \& Swales, 2016) and EAP lessons (Lee, 2016). These models serve to analyze the whole genre or a certain part of it in a discipline-specific or cross-disciplinary way. In the early 1980s, for instance, Dubois (1980) studied the generic structure of biomedical presentations and offered a model consisting of two parts (i.e., Listener orientation and Content orientation) for their introductions. In the early 1990s, however, Thompson (1994) studied the introduction sections of lectures from various disciplines and offered a clear framework with two functions (i.e., Setting up lecture framework and Putting topic in context), each of which consists of several sub-elements such as Announcing topic, Indicating scope, and Showing importance/relevance of topic. This model has been referenced by many analysts of spoken genres. For instance, consulting this framework and two other models (i.e., Dubois, 1980; Swales, 1990), Carter-Thomas and Rowley-Jolivet (2003) analyzed scientific conference presentations in the disciplines of geology, medicine, and physics. Their model included elements from the frameworks they made references and consisted of three moves (i.e., Setting up the framework, Contextualizing the topic, and Research rationale) with several steps. Similarly, using the Swales' move-analysis framework and functions found by Thompson (1994), Lee (2009) studied academic lecture introductions with an emphasis on class size and he offered a threemove framework (i.e., Warming up, Setting up the lecture framework, and Putting the topic in context). This framework was used by Shamsudin and Ebrahimi (2013) in their study into the engineering lecture introductions. They found the same moves in Lee's model but extended it by adding a few new steps (e.g., Announcing the start of the lecture, and Reviewing earlier lectures). Just as Lee (2009), Cheng (2012) studied the effect of class size on the rhetorical features of academic lectures but she focused on lecture closings. She developed a framework with three stages (i.e., Preending, Ending, and Post-ending) and 15 strategies (e.g., Indicating the end of the lecture, Answering students' questions, and Calling for attention).

In terms of the analysis of written genres, there also exist models to identify the rhetorical features with a move-based approach. These models vary in their moves and steps since studies cover a wide variety of genres such as research articles (Swales, 1990), theses/dissertations (Kwan, 2006), letters of application (Ding, 2007), grant proposals (Connor, 2000), conference proposals (Halleck \& Connor, 2006), business letters (Dos Santos, 2002) and call for papers for academic conferences (Yang, 2015). Among these genres, research articles and theses/dissertations have been investigated widely. Therefore, many of the models are for these two genres. Of these models, some are sectionspecific. The pioneering study of Swales (1990), for instance, was a study of this type and, as 
mentioned above, it analyzed the introduction sections of research articles from different disciplines. Following Swales, many studies have analyzed introductions. These studies have identified the rhetorical structures of introductions from different disciplines such as computer engineering (Anthony, 1999), educational psychology (Loi, 2010), applied linguistics (Hirano, 2009), economics (Lakic, 1997), and physical sciences (Taylor \& Chen, 1991). It should be noted that although based on Swales' (1990) section-specific model, some studies proposed models for the whole body of the research articles with IMRD (Introduction, Method, Results, and Discussion) structure. Nwogu (1997), for instance, applied Swales' model to medical research papers and identified a schema of 11 moves consisting of nine normally required and two optional moves. Kanoksilapatham (2005), similarly, extended the application of Swales' model to the biochemistry research articles and developed a structure of 15 moves: three for the Introduction section and four for each of the Methods, Results, and Discussion sections.

Among the section-specific models except those for introduction sections which have been studied extensively, there are also models for literature reviews (e.g., Kwan, 2006), methods sections (e.g., Cotos, Huffman, \& Link, 2017), and post-method sections (e.g., Yang \& Allison, 2003). Brett's (1994) model for the results sections and Dudley-Evans' (1994) model for discussion sections are among these models. In the former, a structure of three main categories (i.e., Metatextual, Presentation, and Comment) is suggested for the results sections of sociology research articles. In the latter, however, a three-part framework (i.e., Introduction, Evaluation, Conclusion) is suggested for the discussion section, the main part of which includes a nine-move sequence. These two models are clear and give a full description of the moves employed in the related sections. Therefore, many analyses of results and discussion sections have been based on these models (e.g., Peacock, 2002; Posteguillo, 1999; Williams, 1999).

Another model used widely for the analysis of discussion sections is that of Hopkins and Dudley-Evans (1988), which analyzed master dissertations in Biology and articles on irrigation and drainage. In this model, an 11-move structure was proposed for the discussion sections: Background Information, Statement of Result, (Un)expected Outcome, Reference to Previous Research (Comparison), Explanation of Unsatisfactory Result, Exemplification, Deduction, Hypothesis, Reference to Previous Research (Support), Recommendation, and Justification. Many researchers have based their models for the discussion section on this model. Swales (1990), for instance, provided a list of eight moves, frequent in discussion sections: Background Information, Statement of Result, (Un)expected Outcome, Reference to Previous Research, Explanation, Exemplification, Deduction and Hypothesis, Recommendation. Also, Holmes (1997) who analyzed research article discussion sections from history, political science, and sociology presented a model which seems to be a modified version of Hopkins and Dudley-Evans' (1988) model. This model included the moves of Background Information, Statement of Result, (Un)expected Outcome, Reference to Previous Research, Explanation of Unsatisfactory Result, Generalization, Recommendation, Outlining Parallel or Subsequent Developments.

Many studies, on the other hand, proposed different moves and steps from those mentioned above. For instance, the model in the study of Berkenkotter and Huckin (1995), which relates the structure of the discussion section to that of introduction, included a three-move structure which reverses the moves given in the CaRS model: Occupying a Niche, (Re)establishing the Niche, Establishing additional territory (Yang and Allison, 2003). Swales and Feak (1994), who emphasized the variation in the discussion sections, however, argued that discussion sections generally have three moves: Consolidate research space, Limitations, and Further research. Similarly, Nwogu (1997) provided a three-move structure and identified the following moves: Highlighting the overall research outcome, Explaining specific research outcomes, Stating research conclusions.

In addition to these models, there is a model used widely for the analysis of the final sections of the studies. This model which was proposed by Yang and Allison (2003) is an extended and modified version of some other models (Nodoushan \& Khakbaz, 2011) and it is a detailed model which investigated all the final sections together. In this model, Results, Discussion, Conclusion, and Pedagogic Implication sections consist of several moves and steps. Through the use of these moves and steps, the results of the study are presented, interpreted, and summarized. Also, pedagogical issues 
are dealt with and suggestions are made for further research. In the model, the moves employed for evaluating the study and for making deductions from the research are common to all concluding sections although some of these moves may differ in their steps. Unlike these common moves, however, the initial moves differ among the sections. Result sections begin with preparatory information for presenting the research results; discussion sections with background information about the main points (e.g., research questions, aims, and purposes, theoretical or methodological information), and conclusion and pedagogic implication sections with a summary of the study. Figure 2 shows the moves and steps in each section.

\begin{tabular}{|c|c|}
\hline & Kesults \\
\hline Move 3-Commenting on results & $\begin{array}{l}\text { Step } 1 \text {-Interpreting results } \\
\text { Step 2-Comparing results with literature } \\
\text { Step 3- Evaluating results } \\
\text { Step 4- Accounting for results }\end{array}$ \\
\hline \multicolumn{2}{|l|}{ Move 4- Summarizing results } \\
\hline Move 5-Evaluating the study & $\begin{array}{l}\text { Step 1- Indicating limitations } \\
\text { Step 2-Indicating gignificance advantage }\end{array}$ \\
\hline \multirow[t]{2}{*}{ Move 6-Deductions from the research } & Step 1-Recommending further research \\
\hline & scussion \\
\hline \multicolumn{2}{|l|}{$\begin{array}{l}\text { Move 1- Background information } \\
\text { Move 2-Reporting results } \\
\text { Move 3- Summarizing results }\end{array}$} \\
\hline Move 4-Commenting on results & $\begin{array}{l}\text { Step } 1 \text {-Interpreting results } \\
\text { Step 2-Comparing results with literature } \\
\text { Step 3-Accounting for results } \\
\text { Step 4- Evaluating results }\end{array}$ \\
\hline \multicolumn{2}{|r|}{ 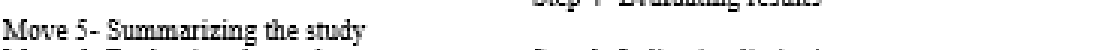 } \\
\hline Move 6-Evaluating the study & $\begin{array}{l}\text { Step 1- Indicating limitations } \\
\text { Step 2- Indicating gignificance advantage } \\
\text { Step 3- Evaluating methodology }\end{array}$ \\
\hline Move 7-Deductions from the research & $\begin{array}{l}\text { Step 1- Making suggestions } \\
\text { Step 2- Recommending further research } \\
\text { Step 3- Drawing pedagogic implication }\end{array}$ \\
\hline \multicolumn{2}{|c|}{ Conclusion } \\
\hline \multicolumn{2}{|l|}{ Move l- Summarizing the study } \\
\hline Move 2-Evaluating the study & $\begin{array}{l}\text { Step 1-Indicating significance advantage } \\
\text { Step 2-Indicating limitations } \\
\text { Step 3-Evaluating methodology }\end{array}$ \\
\hline Move 3-Deductions from the research & $\begin{array}{l}\text { Step 1-Recommending further research } \\
\text { Step 2- Drawing pedagogic implication }\end{array}$ \\
\hline \multicolumn{2}{|c|}{ Pedagogic Implications } \\
\hline \multicolumn{2}{|l|}{ Move l- Summarizing the atudy } \\
\hline Move 2-Dealing with pedagogic issues & $\begin{array}{l}\text { Step 1- Indicating necessity for pedagogic change } \\
\text { Step 2-Drawing pedagogic implications }\end{array}$ \\
\hline Move 3-Evaluating the study & $\begin{array}{l}\text { Step 1- Indicating limitations } \\
\text { Step 2-Indicating significance/ advantage }\end{array}$ \\
\hline Move 4-Deductions from the research & Step 1-Recommending further research \\
\hline
\end{tabular}

Figure 2. Yang and Allison's (2003) Move-Analysis Model

It should be noted that this model and others reviewed above are among those which are used commonly in genre analysis studies. In the related literature, there are several models with a move-step format that can be used for the analysis of spoken and written genres. These models may differ in their moves and steps as the investigated genres vary. However, it seems that the studies have generally 
offered whole-genre or section-specific models, following Swales' (1990) pioneering study. These models have served for the analysis of the structural organization of different types of texts. Also, studies based on these models have shown the applicability of the move-step analysis in different genres. The table below provides information regarding the studies reviewed in this study.

Table 1.

Move Analysis Studies Reviewed in the Present Study

\begin{tabular}{|c|c|c|}
\hline Year & Author(s) & Title \\
\hline 1980 & Dubois & Genre and structure of biomedical speeches \\
\hline 1981 & Swales & Aspects of article introductions \\
\hline 1988 & $\begin{array}{l}\text { Hopkins \& } \\
\text { Dudley-Evans }\end{array}$ & $\begin{array}{l}\text { A genre-based investigation of the discussion sections in articles and } \\
\text { dissertations }\end{array}$ \\
\hline 1990 & Swales & Genre analysis: English in academic and research settings \\
\hline 1991 & Taylor \& Chen & $\begin{array}{l}\text { Linguistic, cultural, and subcultural issues in contrastive discourse } \\
\text { analysis: Anglo-American and Chinese scientific texts }\end{array}$ \\
\hline 1994 & Brett & A genre analysis of the results section of sociology articles \\
\hline 1994 & Dudley-Evans & Genre analysis: An approach to text analysis for ESP \\
\hline 1994 & Thompson & $\begin{array}{l}\text { Frameworks and contexts: A genre-based approach to analyzing } \\
\text { lecture introductions }\end{array}$ \\
\hline 1995 & $\begin{array}{l}\text { Berkenkotter \& } \\
\text { Huckin }\end{array}$ & $\begin{array}{l}\text { Genre knowledge in disciplinary communication: Cognition/ culture/ } \\
\text { power }\end{array}$ \\
\hline 1997 & Holmes & $\begin{array}{l}\text { Genre analysis, and the social sciences: An investigation of the } \\
\text { structure of research article discussion sections in three disciplines }\end{array}$ \\
\hline 1997 & Lakic & Genre analysis of article introductions in economics \\
\hline 1997 & Nwogu & The medical research paper: Structure and functions \\
\hline 1999 & Anthony & $\begin{array}{l}\text { Writing research article introductions in software engineering: How } \\
\text { accurate is a standard model? }\end{array}$ \\
\hline 1999 & Posteguillo & The schematic structure of computer science research articles \\
\hline 1999 & Williams & $\begin{array}{l}\text { Results sections of medical research articles: Analysis of rhetorical } \\
\text { categories for pedagogical purposes }\end{array}$ \\
\hline 2000 & Connor & $\begin{array}{l}\text { Variation in rhetorical moves in grant proposals of US humanists and } \\
\text { scientists }\end{array}$ \\
\hline 2002 & Dos Santos & Genre analysis of business letters of negotiation \\
\hline 2002 & Peacock & Communicative moves in the discussion section of research articles \\
\hline 2002 & Samraj & Introductions in research articles: Variations across disciplines \\
\hline 2003 & $\begin{array}{l}\text { Carter-Thomas \& } \\
\text { Rowley-Jolivet }\end{array}$ & $\begin{array}{l}\text { Analyzing the scientific conference presentation }(\mathrm{CP}), \mathrm{A} \\
\text { methodological overview of a multimodal genre }\end{array}$ \\
\hline 2003 & Yang \& Allison & $\begin{array}{l}\text { Research articles in applied linguistics: moving from results to } \\
\text { conclusions }\end{array}$ \\
\hline 2005 & Kanoksilapatham & Rhetorical structure of biochemistry research articles \\
\hline 2006 & Halleck \& Connor & Rhetorical moves in TESOL conference proposals \\
\hline 2006 & Kwan & $\begin{array}{l}\text { The schematic structure of literature reviews in doctoral theses of } \\
\text { applied linguistics. }\end{array}$ \\
\hline 2007 & Ding & $\begin{array}{l}\text { Genre analysis of personal statements: Analysis of moves in } \\
\text { application essays to medical and dental schools }\end{array}$ \\
\hline 2009 & Hirano & $\begin{array}{l}\text { Research article introductions in English for specific purposes: A } \\
\text { comparison between Brazilian Portuguese and English }\end{array}$ \\
\hline 2009 & Lee & $\begin{array}{l}\text { Size matters: An exploratory comparison of small-and large-class } \\
\text { university lecture introductions. }\end{array}$ \\
\hline 2010 & Loi & $\begin{array}{l}\text { Research article introductions in Chinese and English: A comparative } \\
\text { genre-based study }\end{array}$ \\
\hline 2012 & Cheng & $\begin{array}{l}\text { "That's it for today": Academic lecture closings and the impact of } \\
\text { class size }\end{array}$ \\
\hline 2013 & $\begin{array}{l}\text { Shamsudin \& } \\
\text { Ebrahimi }\end{array}$ & Analysis of the moves of engineering lecture introductions \\
\hline 2015 & Yang & $\begin{array}{l}\text { "Call for papers": Analysis of the schematic structure and lexico- } \\
\text { grammar of CFPs for academic conferences }\end{array}$ \\
\hline
\end{tabular}




\begin{tabular}{lll}
\hline 2016 & Lee & $\begin{array}{l}\text { "There's intentionality behind it...": A genre analysis of EAP } \\
\text { classroom lessons. }\end{array}$ \\
\hline 2016 & Mežek \& Swales & Ph.D. defenses and vivas \\
\hline 2017 & $\begin{array}{l}\text { Cotos, Huffman, \& } \\
\text { Link }\end{array}$ & $\begin{array}{l}\text { A move/step model for methods sections: Demonstrating rigour and } \\
\text { credibility }\end{array}$ \\
\hline
\end{tabular}

\section{Metadiscourse elements and classifications}

Metadiscourse is multifunctional. It functions in a text not only to organize the content but also to engage the audience and indicate the author's stance and perspective. Therefore, it can be realized through many linguistic devices from words and clauses to punctuation and typographical markers (Crismore, Markkanen, \& Steffensen, 1993). As a result, it has been termed, defined, and classified in many ways.

In defining and classifying metadiscourse, many researchers have made references to the metafunctions offered by Halliday in his functionalist model in the 1960s. In the model, Halliday made a distinction between three metafunctions of language (i.e., ideational, interpersonal, and textual) which are different from each other but act simultaneously. The ideational function is the use of language to express our experiences, the textual function is the use of language to create coherent and cohesive texts, and the interactional function is the use of language to interact with each other. This tripartite distinction of metafunctions has been taken as a starting point for many classifications of metadiscourse. However, there seems to be disagreement between many researchers about the metafunctions to be included in the scope of metadiscourse. That is, the researchers have investigated and classified metadiscourse either for just its textual function or both its textual and interpersonal functions mainly because of their approaches to metadiscourse: broad or narrow, also called integrative or non-integrative. According to Adel (2006), in a broad approach, metadiscourse covers linguistic resources used for both textual and interpersonal functions whereas in the narrow approach it just consists of the elements used for textual functions (Cao \& Hu, 2014). She states that "the key difference between the two approaches is the inclusion of interpersonal categories such as expressions of stance" (Adel, 2006, p. 171) and discusses that broad approach is too broad since it includes stance and narrow approach is too narrow since it only considers the text itself and ignores the writer and the reader of the text. As a solution, she offers a reflexive model of metadiscourse. "The interactive approach views metadiscourse mainly as a form of interaction between text participants while the reflexive approach sees metadiscourse principally as a form of linguistic reflexivity" (Zhang, Sun, Peng, Gan, \& Yu, 2017, p. 107). Based on the different functions of language, metalinguistic, expressive, and directive (Jacobson, 1960), corresponding to text-code, writer, and reader respectively, Adel (2006) classifies metadiscourse into four types: text-oriented (e.g., in this essay), writer-oriented (e.g., as I stated above), reader-oriented (e.g., so you may be thinking ...), and participant-oriented (e.g., as we have seen).

Unlike Adel, many researchers base their taxonomies on Halliday's macro-functions of language and follow a narrow or broad approach. Researchers following the narrow approach limit metadiscourse to the textual function and they commonly use the term metatext, introduced by Enkvist in 1975. For instance, Mauranen (1993a), as a prominent researcher taking a narrow approach to metadiscourse, analyzed the texts according to a classification of four types: connectors (e.g., however, for example, as a result), reviews (e.g., so far we have assumed that), previews (e.g., we show below that), and action markers (e.g., to express this argument, to illustrate the ...). Based on the degree of explicitness, Mauranen's (1993b) other study discussed the term reflexivity, called metadiscourse or metatext by many researchers. Classified into two main categories (i.e., High explicit and Low explicit), reflexive expressions were considered important to make the text more interactive and reader-friendly. In the following years, Bunton (1999) added new dimensions to the analysis (i.e., the scope of the text referred to and the distance over which it operates). He made a distinction between the types of metatextual references and offered his own categories (i.e., Text references, Nonlinear text references, Inter-text references, Text act markers, Text connectors, and Text glosses). His analysis of metatext in Ph.D. dissertations revealed the efficacy of the model to investigate metatextual references at different levels (e.g., thesis, chapter, paragraph). 
Researchers taking a broad approach, on the other hand, include both textual and interpersonal elements in their metadiscourse taxonomies. In one of the earliest studies of this kind, metadiscourse was discussed as a part of a writer's style. In this study entitled Style: Lessons in Clarity and Grace by Williams (1981), metadiscourse was defined as a language referring to the writer's intentions (e.g., to sum up, candidly, I believe), directions to the reader (e.g., note that, consider now, as you see) and the structure of the text (e.g., first, second, finally, therefore, however). In the study, Williams (1981) offered a classification of metadiscourse with three common types: Hedges and emphatics, Sequencers and topicalizers, Narrators and attributors (Crismore, 1983). Hedges and emphatics indicate the level of certainty the writer has for the claim he makes. Hedges (e.g., possibly, in my opinion, perhaps, may, might) decrease the level of certainty, while emphatics (e.g., it is clear that, certainly, obviously, as everyone knows, of course) increase it. Sequencers and topicalizers, on the other hand, contribute to the coherence of the text and they are used to make the text easier to comprehend. Hence the name, sequencers (e.g., The first thing I want to say about this subject is ...) help to present to content sequentially and topicalizers (e.g., in regard to, where $\mathrm{x}$ is concerned, in the matter of, turning now to, there is/are) serve to take the readers' attention to a certain point intended by the writer. Finally, narrators and attributors indicate the source of the ideas and facts given in the text. If the source is given directly by the writer in a narrative form, they are called narrators (e.g., I think, I have concluded), and if the source is given indirectly, then they are called attributors (e.g., it has been found, it is seen, it was noted).

As in Williams' (1981) study, metadiscourse was considered as a stylistic device in Crismore's (1983) study. Based on the analysis of metadiscourse elements in school and non-school social science texts, Crismore (1983) offered a classification with two general categories: informational and attitudinal. The former "serves to direct readers how to understand the primary message by referring to its content and structure, and the author's purposes or goals" (p.11), whereas the latter "serves to direct readers how to take the author, that is, how to understand the author's perspective or stance toward the content or structure of the primary discourse" (p.12).

The first category, informational metadiscourse, consists of four types: goals (e.g., the purpose of this unit is to ...) explaining the purpose, pre-plans (e.g., this chapter is about ...) introducing the content and structure, post-plans (e.g., we have argued earlier that ...) reviewing about the content and structure and topicalizers (e.g., let us now turn to ...) making topic shifts. The second category, attitudinal metadiscourse, also has four sub-categories: saliency (e.g., the most crucial component is ...) referring to the importance of the idea, emphatics (e.g., this is, of course, is ...) indicating the degree of certainty of the writer of his claim, hedges (e.g., perhaps, worst of all was ...) indicating the degree of uncertainty and finally evaluative (e.g., I think, it is interesting that ...) referring to the writer's attitude towards the idea or fact given (Crismore, 1983, pp. 12-14).

Similar to the classification of Crismore (1983) in form, having two broad categories, but different from it in content, another metadiscourse taxonomy was offered by Vande Kopple in 1985. Based on Halliday's distinction between three metafunctions of language, the types of metadiscourse given in the book of Williams (1981) on style, and the discussions of Lautamatti (1978) on non-topical materials, Vande Kopple offered a classification with seven types serving for two main functions: textual and interpersonal. He explained these two types as follows:

That is, some kinds of metadiscourse (the "interpersonal") are communication about communication in that they can help us express our personalities and our reactions to the propositional content of our texts and characterize the interaction we would like to have with our readers about that content. ... Other kinds of metadiscourse (the "textual") are communication about communication in that they can help us show how we link and relate individual propositions so that they form a cohesive and coherent text and how individual elements of those propositions make sense in conjunction with the other elements of the text in a particular situation (pp. 86-87).

Vande Kopple's (1985) classification consisted of text connectives (e.g., first, next) connecting different parts of the text, code glosses (e.g., defined as, which means) providing the appropriate meanings of words, illocution markers (e.g., I hypothesize that, we claim that, to sum up) 
expressing the performed discourse acts, validity markers (e.g., perhaps, may, might, clearly, undoubtedly) indicating the degree of certainty or uncertainty for the propositional content, narrators (e.g., according to James, Mrs. Wilson announced that) specifying the source of the information given, attitude markers (e.g., surprisingly, I find it interesting that) indicating the author's attitude towards the content and commentary (e.g., most of you will oppose the idea that, you might wish to read the last chapter first) addressing readers and thus establishing a dialogue with them.

This classification, as well as many others such as Williams' (1981) and Crismore's (1983) classifications, was criticized by Beauvais (1989) for being imprecise in terms of their categories. In an attempt to create a more precise definition and classification of metadiscourse, Beauvais studied metadiscourse in the context of speech act theory and offered a new classification consisting of two main categories (i.e., Primary expositive illocutionary acts and Secondary expositive illocutionary acts). The first of these categories referred to the acts performed directly by the writer or speaker himself and was expressed in first-person subject pronouns. The second category, however, referred to the acts performed by someone other than the writer or speaker and was expressed in either second- or third-person subjects (Beauvais, 1989).

Based on the three macro-functions of language, Crismore et al. (1993) also suggested a metadiscourse taxonomy. By modifying the classification suggested by Vande Kopple (1985), they offered their own categories. First, they divided Vande Kopple's seven types of metadiscourse into two main groups as textual (including text connectives, code glosses, illocution markers, narrators) and interpersonal (including validity markers, attitude markers, commentaries), and then they formed their categories still under the main categories of textual and interpersonal but with different subtypes. The first difference of this classification from the previous study is that textual metadiscourse was divided into two types -textual and interpretive- which were further subdivided. Textual markers were logical connectives, sequencers, reminders, and topicalizers, while interpretive markers were code glosses, illocution markers, and announcements. The second difference, however, appeared in the category of interpersonal metadiscourse. In this category, validity markers, attitude markers, and commentaries were included. However, three separate categories (i.e., hedges, certainty markers, attributors) were used instead of only one group named validity markers, and the type called attributors also consisted of elements named as narrators in Vande Kopple's (1985) classification since both types indicate the source of the information or idea given in the text. In the study, it was stated that although narrators (e.g., John claims that) are not references to authorities as attributors (e.g., Einstein claimed that), they also indicate the source of textual information, and serve to support the argument. Besides, many categorizations of the expressions as narrators and attributors seem inconsistent and, as a result, these two groups were combined in their classification of metadiscourse. In addition to these differences from Vande Kopple's study, Crismore et al. (1993) also included punctuation in their analysis. Markers used to provide a further explanation (e.g., But the measures are not sufficient: mankind does not have time ...) or a better interpretation of the text (e.g., ... we, the general public "promote" smoking) were considered as metadiscourse elements.

Among the subsequent classifications, those provided by Hyland and his colleagues have been used widely. In these classifications, like others with a broad approach, metadiscourse is discussed from not only textual but also interpersonal perspectives "based on a view of writing as a social and communicative engagement between a writer and readers" (Hyland, 1998, p. 3). By modifying Crismore et al.'s (1993) classification, Hyland (1998) divided metadiscourse elements into two categories as textual and interpersonal with their subcategories. Similar to these modified versions, Hyland and Tse (2004) suggested another classification. The main difference between this classification and previously modified versions by Hyland was the terms used for main and subcategories. For the main categories of textual and interpersonal, two other terms -interactive and interactional- were used, based on the idea that "all metadiscourse is interpersonal in that it takes account of the reader's knowledge, textual experiences, and processing needs and that it provides writers with an armoury of rhetorical appeals to achieve this" (Hyland \& Tse, 2004, p. 161). Both having an interpersonal function, "interactive resources help to guide the reader through the text while interactional resources involve the reader collaboratively in the development of the text" (Thompson, 2001, p. 58). For the subcategories, however, the terms logical connectives, emphatics, relational 
markers, and person markers were replaced by the terms transitions, boosters, engagement markers, and self-mentions respectively. Figure 3 shows the interactive and interactive metadiscourse markers in Hyland and Tse's (2004) taxonomy. Including several types of metadiscoursal elements, this model has been used in many text analysis studies. These studies have analyzed texts from different genres, disciplines, and languages in terms of the metadiscourse employed.

\begin{tabular}{|c|c|c|}
\hline Category & Function & Examples \\
\hline Interactive resources & (Help to guide reader through the text) & \\
\hline Transitions & express semantic relation between main clauses & in addition/but/thus/and \\
\hline Frame markers & refer to discourse acts, sequences, or text stages & finally/to conclude/my purpose here is to \\
\hline Endophoric markers & refer to information in other parts of the text & noted above/see $\mathrm{Fig} /$ in section 2 \\
\hline Evidentials & refer to source of information from other texts & according to $\mathrm{X} /(\mathrm{Y}, 1990) / \mathrm{Z}$ states \\
\hline Code glosses & help readers grasp functions of ideational material & namely/e.g./such as/in other words \\
\hline Interactional resources & (Involve the reader in the argument) & \\
\hline Hedges & withhold writer's full commitment to proposition & might/perhaps/possible/about \\
\hline Boosters & emphasize force or writer's certainty in proposition & in fact/definitely/it is clear that \\
\hline Attitude markers & express writer's attitude to proposition & unfortunately/I agree/surprisingly \\
\hline Engagement markers & explicitly refer to or build relationship with reader & consider/note that/you can see that \\
\hline Self-mentions & explicit reference to author(s) & I/we/my/our \\
\hline
\end{tabular}

Figure 3. Hyland and Tse's (2004) Metadiscourse Taxonomy

To conclude, the related literature indicates that there are several studies presenting taxonomies or classifications that can be used for the analysis of texts in terms of the metadiscourse markers employed. The table below provides information regarding the studies reviewed in this study.

Table 2.

Metadiscourse Analysis Studies Reviewed in the Present Study

\begin{tabular}{lll}
\hline Year & Author(s) & Title \\
\hline 1981 & Williams & Style: Lessons in clarity and grace \\
\hline 1983 & Crismore & $\begin{array}{l}\text { Metadiscourse: What it is and how it is used in school and non- } \\
\text { school social science texts }\end{array}$ \\
\hline 1985 & Vande Kopple & Some exploratory discourse on metadiscourse \\
\hline 1989 & Beauvais & A speech act theory of metadiscourse \\
\hline 1993 & $\begin{array}{l}\text { Crismore, Markkanen, } \\
\text { \& Steffensen }\end{array}$ & $\begin{array}{l}\text { Metadiscourse in persuasive writing: A study of texts written } \\
\text { by American and Finnish university students }\end{array}$ \\
\hline 1993 a & Mauranen & $\begin{array}{l}\text { Contrastive ESP rhetoric: Metatext in Finnish-English } \\
\text { economics texts }\end{array}$ \\
\hline $1993 b$ & Mauranen & $\begin{array}{l}\text { Cultural differences in academic discourse-problems of a } \\
\text { linguistic and cultural minority }\end{array}$ \\
\hline 1998 & Hyland & $\begin{array}{l}\text { Persuasion and context: The pragmatics of academic } \\
\text { metadiscourse. }\end{array}$ \\
\hline 1999 & Bunton & The use of higher-level metatext in Ph.D. theses \\
\hline 2004 & Hyland \& Tse & Metadiscourse in academic writing: A reappraisal \\
\hline 2006 & Adel & Metadiscourse in L1 and L2 English \\
\hline
\end{tabular}




\section{Conclusion and Implications}

Genre analysis in ESP aims to identify the structural patterns of a given genre in terms of a series of moves and steps, based on the idea that genres are identifiable by their organizational and linguistic features. Focusing typically on academic and professional genres, it deals with the communicative purposes and rhetorical structures of discipline-specific genres. In the analysis process, the moves, steps, and their linguistic features are identified and the rationale behind the use of these features is explained. Such an analysis, first of all, informs the text producers and audiences about the features of the genre they use and consequently contributes to the organization of the texts written and understanding of the texts read or listened to. Secondly, it shows how genres are used by the members of different discourse communities and thus helps text producers organize their texts in a way that will enable them to participate in the target discourse community and communicate with its members effectively. Thirdly, it contributes to the teaching and learning of writing in academic and research settings and makes crucial contributions to pedagogy. It is basically for these reasons that related literature has continuously extended since the 1980s. Methodologically, many studies (e.g., DudleyEvans, 1994; Holmes, 1997; Swales, 1990; Yang \& Allison, 2003) have made move-analysis based on the identification of several moves and steps employed in texts. In addition to these move-based studies, many other studies have been devoted to the analysis of genres from a linguistic perspective. In these studies (e.g., Bunton, 1999; Crismore, 1983; Hyland \& Tse, 2004; Vande Kopple, 1985), another type of analysis called metadiscourse analysis has been focused on.

This study has provided information about the models and taxonomies used commonly in the move and metadiscourse analysis studies. It has shown that following the first move-based model developed by Swales in 1981, many whole-genre or section-specific move analysis models have been proposed and used for the analysis of genres. Similarly, after the introduction of the term 'metadiscourse' by Harris in 1959, many metadiscourse elements have been identified, metadiscourse classifications have been offered and analyses of metadiscourse markers in different texts have been conducted.

Devoted to the review of the most commonly used models and taxonomies in genre analysis literature, this study, first of all, has implications for the teaching and learning of genre analysis. It has provided knowledge about the ESL approach to genre and genre analysis, and such knowledge may help students of academic writing learn about the basics of genre analysis in ESP. Also, it has reviewed the move analysis models and metadiscourse taxonomies proposed over many years and this review may be used for the teaching of move and metadiscourse analyses. Secondly, the study may assist researchers, especially those who are new in the field, to review the models and taxonomies that can be used for genre analysis. It may guide the researchers in their choice of the frameworks they could use in their studies. Further research studies may extend the issue to the studies applying the models and taxonomies mentioned in this review and provide a review of these studies and their results.

\section{Ethics Statement}

In this study, we declare that the rules stated in the "Higher Education Institutions Scientific Research and Publication Ethics Directive" are complied with and that we do not take any of the actions based on "Actions Against Scientific Research and Publication Ethics". At the same time, we declare that there is no conflict of interest between the authors, that all authors contribute to the study, and that all the responsibility belongs to the article authors in case of all ethical violations.

\section{Copyrights}

The works published in the e-Kafkas Journal of Educational Research are licensed under the Creative Common Attribution-Noncommercial 4.0 International License. 


\section{References}

Adel, A. (2006). Metadiscourse in L1 and L2 English. Amsterdam/Philadelphia: John Benjamins. Allison, D. (2002). Approaching English language research. Singapore: Singapore University Press.

Anthony, L. (1999). Writing research article introductions in software engineering: How accurate is a standard model? IEEE Transactions on Professional Communication, 42, 38-46. doi: $10.1109 / 47.749366$

Bawarshi, A. S. \& Reiff, M. J. (2010). Genre: An introduction to history, theory, research, and pedagogy. West Lafayette, Ind: Parlor Press.

Beauvais, P. J. (1989). A speech act theory of metadiscourse. Written Communication, 6, 11-30. doi: $10.1177 / 0741088389006001002$

Berkenkotter, C. \& Huckin, T. N. (1995). Genre knowledge in disciplinary communication: Cognition/ culture/ power. Hillsdale, NJ: Lawrence Erlbaum.

Brett, P. (1994). A genre analysis of the results section of sociology articles. English for Specific Purposes, 13(1), 47-59. doi:10.1016/0889-4906(94)90024-8

Bunton, D. (1999). The use of higher level metatext in Ph.D. theses [Supplement 1]. English for Specific Purposes, 18, S41-S56. doi:10.1016/S0889-4906(98)00022-2

Cao, F., \& Hu, G. (2014). Interactive metadiscourse in research articles: A comparative study of paradigmatic and disciplinary influences. Journal of Pragmatics, 66, 15-31. doi:10.1016/j.pragma.2014.02.007

Carter-Thomas, S., \& Rowley-Jolivet, E. (2003). Analysing the scientific conference presentation (CP), A methodological overview of a multimodal genre. ASp. la revue du GERAS, 39-40, 5972. doi:10.4000/asp.1295

Cheng, S.W. (2012). "That's it for today": Academic lecture closings and the impact of class size. English for Specific Purposes, 31, 234-248. doi:10.1016/j.esp.2012.05.004

Connor, U. (2000). Variation in rhetorical moves in grant proposals of US humanists and scientists. Text-Interdisciplinary Journal for the Study of Discourse, 20, 1-28. doi:10.1515/text.1.2000.20.1.1

Cotos, E., Huffman, S., \& Link, S. (2017). A move/step model for methods sections: Demonstrating rigour and credibility. English for Specific Purposes, 46, 90-106. doi:10.1016/j.esp.2017.01.001

Crismore, A. (1983). Metadiscourse: What it is and how it is used in school and non-school social science texts (Report No. 273). Urbana-Champaign: University of Illinois, Center for the Study of Reading.

Crismore, A., Markkanen, R., \& Steffensen, M. S. (1993). Metadiscourse in persuasive writing: A study of texts written by American and Finnish university students. Written Communication, 10, 39-71. doi: $10.1177 / 0741088393010001002$

Crookes, G. (1986). Towards a validated analysis of scientific text structure. Applied Linguistics, 7 , 57-70. doi:10.1093/applin/7.1.57

Ding, H. (2007). Genre analysis of personal statements: Analysis of moves in application essays to medical and dental schools. English for Specific Purposes, 26, 368-392. doi:10.1016/j.esp.2006.09.004

Dos Santos, V.B.M.P. (2002). Genre analysis of business letters of negotiation. English for Specific Purposes, 21, 167-199. doi:10.1016/S0889-4906(00)00028-4

Dubois, B. L. (1980). Genre and structure of biomedical speeches. Forum Linguisticum, 5, 140-168.

Dudley-Evans, T. (1994). Genre analysis: An approach to text analysis for ESP. In M. Coulthard (Ed.), Advances in written text analysis (pp. 219-228). London: Routledge.

Enkvist, (1978). Introduction: Text, Cohesion, and Coherence. In J.O.Ostman (Ed.), Reports on text linguistics: Cohesion and semantics (pp. 99-131). Finland: Abo Akademi. Retrieved from https://files.eric.ed.gov/fulltext/ED275183.pdf

Flowerdew, J. (2002). Genre in the classroom: A linguistic approach. In A.M.Johns (Ed.), Genre in the classroom: Multiple perspectives (pp.91-102). Mahwah, NJ: Lawrence Erlbaum.

Halleck, G. B., \& Connor, U. M. (2006). Rhetorical moves in TESOL conference proposals. Journal of English for Academic Purposes, 5, 70-86. doi:10.1016/j.jeap.2005.08.001 
Halliday, M. A. K. (1973). The functional basis of language. In J. Webster (Ed.), On language and linguistics (pp. 298-323). London: Continuum.

Harris, Z. S. (1959a). The transformational model of language structure. Anthropological Linguistics, 1(1), 27-29. Retrieved from www.jstor.org/stable/30022172

Harris, Z. S. (1959b). Linguistic transformations for information retrieval. Proceedings of the International Conference on Scientific Information: Vol.2. Organization of Information for Storage and Retrospective Search: Intellectual problems and equipment considerations in the design of new systems (pp. 937-951). Washington, DC: The National Academies Press. doi:10.17226/10866.

Hirano, E. (2009). Research article introductions in English for specific purposes: A comparison between Brazilian Portuguese and English. English for Specific Purposes, 28, 240-250. doi:10.1016/j.esp.2009.02.001

Holmes, R. (1997). Genre analysis, and the social sciences: An investigation of the structure of research article discussion sections in three disciplines. English for Specific Purposes, 16, 321 337. doi:10.1016/S0889-4906(96)00038-5

Hopkins, A., \& Dudley-Evans, T. (1988). A genre-based investigation of the discussion sections in articles and dissertations. English for Specific Purposes, 7, 113-121. doi:10.1016/08894906(88)90029-4

Hyland, K. (1998). Persuasion and context: The pragmatics of academic metadiscourse. Journal of Pragmatics, 30(4), 437-455. doi:10.1016/S0378-2166(98)00009-5

Hyland, K. (2004). Genre and second language writing. Ann Arbor: The University of Michigan Press.

Hyland, K., \& Tse, P. (2004). Metadiscourse in academic writing: A reappraisal. Applied Linguistics, 25(2), 156-177. doi:10.1093/applin/25.2.156

Jacobson, R. (1960). Linguistics and Poetics. In T. A. Sebeok (Ed.), Style in Language (pp. 350-377). Cambridge: M.I.T. Press.

Johns, A. M. (2013). Rhetorical genre studies (RGS) and the teaching of EFL reading and writing-or genre is much more than text structure. In X. Deng. \& R. Seow (Eds.), Alternative pedagogies in the English language \& communication classroom (pp. 1-8). Singapore: CELC.

Kanoksilapatham, B. (2005). Rhetorical structure of biochemistry research articles. English for Specific Purposes, 24(3), 269-292. doi:10.1016/j.esp.2004.08.003

Kwan, B. S. (2006). The schematic structure of literature reviews in doctoral theses of applied linguistics. English for Specific Purposes, 25, 30-55. doi:10.1016/j.esp.2005.06.001

Lakic, I. (1997). Genre analysis of article introductions in economics. ASp. la revue du GERAS, (1518), 409-426. doi:10.4000/asp.3239

Lautamatti, L. (1978). Observations on the development of the topic in simplified discourse. AFinLAn vuosikirja, 8(22), 71-104. Retrieved from https://journal.fi/afinlavk/article/view/57428

Lee, J. J. (2009). Size matters: An exploratory comparison of small-and large-class university lecture introductions. English for Specific Purposes, 28, 42-57. doi:10.1016/j.esp.2008.11.001

Lee, J. J. (2016). “There's intentionality behind it...”: A genre analysis of EAP classroom lessons. Journal of English for Academic Purposes, 23, 99-112. doi:10.1016/j.jeap.2015.12.007

Loi, C. K. (2010). Research article introductions in Chinese and English: A comparative genre-based study. Journal of English for Academic Purposes, 9(4), 267-279. doi:10.1016/j.jeap.2010.09.004

Martin, J. R. (2002). Meaning beyond the clause: SFL perspectives. Annual Review of Applied Linguistics, 22, 52-74. doi:10.1017/S026719050200003X

Mauranen, A. (1993a). Contrastive ESP rhetoric: Metatext in Finnish-English economics texts. English for Specific Purposes, 12(1), 3-22. doi:10.1016/0889-4906(93)90024-I

Mauranen, A. (1993b). Cultural differences in academic discourse-problems of a linguistic and cultural minority. AFinLAn vuosikirja, 51, 157-174. Retrieved from https://journal.fi/afinlavk/article/view/57853

Mežek, Š., \& Swales, J. (2016). Ph.D. defences and vivas. In K. Hyland \& P. Shaw (Eds.), The Routledge Handbook of English for Academic Purposes (pp. 361-375). London: Routledge.

Miller, C. R. (1984). Genre as social action. Quarterly Journal of Speech, 70, 151-167. doi: $10.1080 / 00335638409383686$ 
Nodoushan, M., \& Khakbaz, N. (2011). Theses 'Discussion' sections: A structural move analysis. International Journal of Language Studies, 5, 111-132. Retrieved from https://files.eric.ed.gov/fulltext/ED521873.pdf

Nwogu, K. N. (1997). The medical research paper: Structure and functions. English for Specific Purposes, 16(2), 119-138. doi:10.1016/S0889-4906(97)85388-4

Paltridge, B. (2011). Genre and English for specific purposes. Retrieved from https://genreacrossborders.org/research/genre-and-english-specific-purposes

Peacock, M. (2002). Communicative moves in the discussion section of research articles. System, 30(4), 479-497. doi:10.1016/S0346-251X(02)00050-7

Pérez-Llantada, C. (2015). Genres in the forefront, languages in the background: The scope of genre analysis in language-related scenarios. Journal of English for Academic Purposes, 19, 10-21. doi:10.1016/j.jeap.2015.05.005

Posteguillo, S. (1999). The schematic structure of computer science research articles. English for Specific Purposes, 18(2), 139-160. doi:10.1016/S0889-4906(98)00001-5

Samraj, B. (2002). Introductions in research articles: Variations across disciplines. English for Specific Purposes, 21(1), 1-17. doi:10.1016/S0889-4906(00)00023-5

Shamsudin, S. \& Ebrahimi, S. J. (2013). Analysis of the moves of engineering lecture introductions. Procedia-Social and Behavioral Sciences, 70, 1303-1311. doi:10.1016/j.sbspro.2013.01.191

Swales, J. M. (1981). Aspects of article introductions (Report No. 1). Birmingham: University of Aston.

Swales, J. M. (1990). Genre analysis: English in academic and research settings. Cambridge: Cambridge University Press.

Swales, J. M. (2011). Aspects of article introductions. Ann Arbor: University of Michigan Press.

Swales, J. M. \& Feak, C. B. (1994). Academic writing for graduate students: Essential tasks and skills. Ann Arbor: University of Michigan Press.

Swales, J. M. \& Feak, C. B. (2004). Academic writing for graduate students: Essential tasks and skills (2nd ed). Ann Arbor: University of Michigan Press.

Taylor, G. \& Chen, T. (1991).Linguistic, cultural, and subcultural issues in contrastive discourse analysis: Anglo-American and Chinese scientific texts. Applied Linguistics, 12, 319-336. doi:10.1093/applin/12.3.319

Thompson, G. (2001). Interaction in academic writing: Learning to argue with the reader. Applied Linguistics, 22(1), 58-78. doi:10.1093/applin/22.1.58

Thompson, S. (1994). Frameworks and contexts: A genre-based approach to analyzing lecture introductions. English for Specific Purposes, 13, 171-186. doi:10.1016/0889-4906(94)90014-0

Vande Kopple, W. J. (1985). Some exploratory discourse on metadiscourse. College Composition and Communication, 36(1), 82-93. doi: 10.2307/357609

Williams, I. A. (1999). Results sections of medical research articles: Analysis of rhetorical categories for pedagogical purposes. English for Specific Purposes, 18, 347-366. doi:10.1016/S08894906(98)00003-9

Williams, J. M. (1981). Style: Lessons in clarity and grace (9th ed.). New York: Pearson Longman.

Yang, R. \& Allison, D. (2003). Research articles in applied linguistics: Moving from results to conclusions. English for Specific Purposes, 22, 365-385. doi:10.1016/S0889-4906(02)00026-1

Yang, W. (2015). "Call for papers": Analysis of the schematic structure and lexico-grammar of CFPs for academic conferences. English for Specific Purposes, 37, 39-51. doi:10.1016/j.esp.2014.06.006

Zhang, M., Sun, W., Peng, H., Gan, Q., \& Yu, B. (2017). A multidimensional analysis of metadiscourse markers across spoken registers. Journal of Pragmatics, 117, 106-118. doi:10.1016/j.pragma.2017.06.00 